\title{
Understanding campaign "axiotechniques": Their nature and practical usage in Ukrainian elections
}

\author{
YEVHEN KUTSENKO
}

$\frac{\text { DE }}{G} \stackrel{\text { DE GRUYTER }}{\text { OPEN }}$

Politics in Central Europe (ISSN: 1801-3422)

Vol. 14, No. 1

DOI: 10.2478/pce-2018-0001

\begin{abstract}
This article seeks to shed more light on Ukraine's parliamentary elections by considering campaign tools that were derived from values in the electorate and used in elections between 2006 and 2012. The influence of political values on the electoral process was pointed out by American political scientists in the mid-20th century. My research demonstrates, however, that the political choices of Ukrainians in the 2006-2012 elections gave rise to campaign techniques that were not based on "classic" political values like freedom, human rights and democracy. Instead, their source was national identity-related values including the importance of a common history, culture and language along with religious and geopolitical preferences. These values differed between the western and central regions of Ukraine on the one hand and the southern and eastern parts of the state on the other. This regional polarisation did not seem very dangerous, however, until the emergence of election campaigns based on political ideology. As ideology gradually lost its mobilising potential, there was a need for an effective new system of political influence. Manipulative techniques were deployed to incite artificial clashes between citizens with different political identities. This article analyses specific uses of these techniques and uncovers links between their application and the destruction of the electoral space in Ukraine as well as the division of the country's real political arena.
\end{abstract}

Keywords: campaign axiotechniques, political manipulation, elections, voters. 


\section{Introduction}

Political elections are the basis for the forming of a representative government with voter legitimation. During election campaigns, politicians (whether independent candidates or representatives of political parties) use different methods to attract citizens' votes. The most effective and therefore dominant approach to competing in election campaigns in modern democratic states relies on campaigning techniques.

The term "campaign techniques" refers first of all to a group of activities that may be pre-designed, planned or spontaneous. These are procedures and technical and information tools designed to ensure the successful nomination of candidates and their election. Additionally, the term describes a set of tools and methods which seek to influence voters using relevant scientific sociological research together with political advertising and public relations (PR) techniques in order to achieve electoral success for a certain political party (or individual candidate).

Given the regularity of elections at different levels of power in Ukraine and the fierceness with which these campaigns are contested, research into the creation, operation and application of election techniques has particular relevance. The theoretical framework for this research includes works by Western authors (for example, Bafumi and Shapiro 2009; Jacobs and Shapiro 2000; Guelke 2012; Byrne 1997; O'Flynn 2010; Emr and Writer 2013; Schaap 2006, Riker 1986, Coons and Weber 2014; Goodin 1980; McDermott 2010) and Ukrainian authors (Rudych and Paharev 2011; Balaban 2007; Myhalchenko 2007; Nagorna 2008; Poltorak 2015; Vydrin 1991; Variy 2003).

Nevertheless, modern political scientists are yet to conduct any detailed research on the development of campaign techniques based on the axiological priorities of Ukrainian regional populations. In fact, the study of values-related campaign techniques lies at the crossroads of several areas of research. These include theories of political manipulation and societal division.

Goodin's (1980) monograph Manipulatory Politics was one of the first attempts to distil the essence of political manipulation. Goodin identified two criteria that seemed central to this phenomenon, noting that this manipulation must be (1) deceptive and (2) contrary to the putative will of its subjects. Coons and Weber (2014) described manipulation as the steering or influencing of others' choices and highlighted three forms this might take: deception, pressuring and the exploitation of emotional vulnerability or character defects.

Riker (1986) defined three key manipulative strategies: (1) controlling the agenda, which involves manipulating the agenda to secure favourable election outcomes; (2) strategic voting, which uses voting procedures to control outcomes and (3) other manipulation in which the context is redefined to create a stronger coalition. 
An independent research field has been established by researchers of various aspects of the manipulation of public opinion (Jacobs - Shapiro 2000, Cheminant - Parrish 2011). From an axiological standpoint, one of the most interesting research areas is the impact of the manipulation of public opinion on political behaviour, particularly in elections, and thus, also on election results. In this regard, the conclusions of McDermott (2010) are particularly important. Using contemporary America as an example, she shows how political leaders manipulate emotions to achieve specific political effects and gain a partisan advantage. McDermott (2010) argues that the most commonly and effectively exploited emotion is fear and that this is very useful for garnering political support. The result, she claims, is that voters lose the ability to make informed choices about leadership and policy because they can only judge the truth and accuracy of information based on their relationship with the information source.

The theory of societal division is also closely connected with McDermott's (2010) work. There are two main versions of this thesis. According to the first, which is more popular among academics, divided societies arise when a new ethnic conflict surfaces or an old one reemerges as a result of a lack of consensus about decision-making procedures or a contest for legitimacy among different ethnic groups. Social scientists analyse divided societies drawing mostly on examples from Northern Ireland, Fiji, Papua New Guinea and South Africa. Among the most effective mechanisms for resolving violent unrest in these countries, they argue, are changes to constitutional and electoral laws.

But using this approach to analyse political problems in Ukraine is incorrect since it fails to reflect the essence of the Ukrainian political reality: modern Ukraine has never had ethnic conflicts and such conflicts do not exist today.

That is why I opt for the second approach to understanding divided societies. This approach makes clear that conflating cultural diversity with political division is a mistake. A divided society isn't merely one that is diverse ethno-culturally. Rather, what makes a society divided is the political salience of the differences among its population - in other words, they are persistent markers of political identity and a basis for political mobilisation. A divided society is, thus, one where ethno-cultural differences have such political weight that they can upset constitutional stability.

We can see that on the one hand, the term "manipulation" is used widely and has several meanings, and on the other, social scientists are interested in specific political misuses that can lead to societal division. Of course, we may also call these misuses "manipulation" but this does not clarify the type of manipulation that we are talking about.

In order to explore this issue, I propose giving the name "axiotechniques" to any efforts to manipulate the political identities and values that divide a society. The term "campaign axiotechniques" does not appear in either Ukrainian or 
foreign scientific discourse, but I introduce it here with the aim of advancing this field of study. By "axiotechniques" (from the Greek axia meaning "value" and techne meaning "art, skill, ability"), I refer to the purposeful manipulation of values of the Ukrainian public in order to mobilise voters and increase the incentive to vote for a specific political party or politician. This manipulation is usually based on the simulation of values. It exaggerates the importance of these values with the goal of deepening splits in a society.

The term "axiotechniques" literally describes the management (manipulation) of the axiological sphere. As such, it is closely connected with axiology, another word derived from the Greek (axiomeans "value" while logos means "science" or "knowledge"). This science of values was founded in 1902 by the French philosopher Paul Lapie. One fairly common view understands axiology as the "study of values and their place in [...] reality and in the structure of [the] value-based world; that is, the relationship of different values together with social and cultural factors and personality structure" (Gubskiy - Korableva 2003: 18-19).

The desire to clarify how political values influence social processes has led various scientists to conduct research in the field. The earliest of these studies appeared in 1944 and considered voters' attitudes to elections (Lazarsfeld - Berelson - Gaudet 1944: 35). This was the work of Lazarsfeld, one of the founders of political sociology scholarship, together with his colleagues at the Department of Applied Research at Columbia University. Lazarsfeld's main conclusion was that the social characteristics of each citizen give rise to a specific set of interests, which in turn generate values (including values related to elections).

More recent researchers have confirmed that political values have a hugely important effect on political processes (Hernandez and Mynor 2015; Parker and Baretto 2013; Goren 2005). According to these scholars, the only way to better understand this problem is to conduct case studies in different parts of the world and collect our findings.

In this vein, this article aims to detail the axiotechniques at work in election campaigns in Ukraine and to analyse how they have been used in practice. My research objectives are therefore twofold:

- to determine the nature, background and causes of campaign axiotechniques and

- to analyse distinctive features of the axiotechniques used in Ukrainian elections from 2004 to 2012.

In order to pursue these objectives, it is necessary to identify significant values and track how they have determined Ukrainians' election choices. I do this by analysing the results of election campaigns in Ukraine. 


\section{Key values and their effects on Ukrainians' election choices}

The political values associated with axiotechniques are not traditional political values such as democracy, freedom of speech, human rights, freedom of assembly or freedom of religion. Instead, they are values that underlie citizens' national identity. Without delving too deeply into various approaches to national identity, I would endorse the view of Stepyko (2011), who defines the term as the "recognition by the citizens of one country that they represent one political nation and respect the shared history, culture, language, religion, territory and state which are their political values" (p. 143).

Belief in a unique civic identity fulfils the political goal of consolidating a society axiologically. That is why the main task of every political regime should be to strive to establish a system of political values that focuses on the general public. A society where this consensus of values has been achieved may be considered stable since the main source of disagreement between individuals and the society has disappeared. When values are out of balance, on the other hand, the system is destablised and the results may be insecurity, disasters, fear and shock. Eventually, this can also lead to the system's destruction.

The basis for the civic consolidation of any nation is the understanding that the "nation is all citizens of the country regardless of their ethnicity, the language they communicate in and the traditions they follow and in which they educate their children" (Kasianov 1999: 136). Sociological research suggests, however, that this view of the Ukrainian nation is shared by only $43.1 \%$ of citizens; in contrast, for $34 \%$ of Ukrainians, the backbone of their society is ethnicity (Razumkov Research Centre 2007). This points to the root of the civic identity crisis in Ukraine.

The percentage of Ukraine's population who identify as Ukrainian citizens remains relatively low: between 1992 and 2015, this figure rose from $45.6 \%$ to just $57.5 \%$. This fact itself is alarming, and we should also consider the quantitative differences in the recognition of the value of Ukrainian citizenship across the country: while $65.1 \%$ of those in the west affirmed the value of this citizenship, the figure in the south was $45.1 \%$ and it was just $38.6 \%$ in Donbass (Institute of Sociology 2015).

At the same time, a sense of Soviet identity has remained fairly strong in Ukraine. In 2013, 34.6\% of citizens expressed their "congenial attitude to the Soviet Union."This position was most common in the east and the south of the country (48\%) followed by the central region (32\%) and the west $(17 \%)$. Roughly $40 \%$ of Ukrainians were still"nostalgic" for the USSR (Zolkina 2013: 15).

These identifications have an obvious negative impact on the outlook of Ukrainians. Sociological research has shown that if Ukrainians had the option of renouncing their citizenship and adopting the nationality of a more prosperous country, $47.3 \%$ would do so (Mostova 2014). 
Nagorna (2008) describes the causes of this situation as follows:

Ukraine, after it had gained... independence and decided on the nation-state paradigm, should have made a meaningful choice in favour of one of the two civic identity models. The first of these prioritises civic consciousness and focuses on the political, legal and humanitarian components of the nation phenomenon. The second model tends to emphasise natural and cultural traits (the concept of "blood and soil"). This model is almost the same as ethnic identity in terms of content. In fact, a hybrid version was selected. This emerged from the tasks of forming a Ukrainian identity based on principles of territory, civilisation and ethnicity. But the efforts of national democrats, who effectively monopolised the ideological strategy in the early independence years, to impose an ethnic model of the nation and a system of preferences based on titularity or "roots," caused a split in social consciousness. This had an immediate and clear regional dimension (p. 56).

Shulman (2005), an American researcher, has objected to aspects of this statement. He claims that after Ukraine failed to create a single platform for national identity, it faced not the choice between civic and ethnic versions of national identity but a more dangerous political reality - alternative versions of ethnic identity. There was a tension between the Ukrainian ethnonationalversion and the eastUkrainian (or, as Bhabhy puts it, "hybrid" (Kryvytska 2015)) version, which was, in fact, Soviet-Russian. These versions, moreover, had clear regional links: Ukrainian ethnonational identity became dominant in western and central Ukraine while the Soviet-Russian version prevailed in the east and the south (Shulman 2005: 65).

\section{Political ideology as the basis for regional polarisation and election preferences (1991-2004)}

Regional differences concerning national identity affect the electoral preferences of Ukraine's population. This division was apparent for the first time in the 1991 presidential election. The election results revealed the impact of geographic polarisation on electoral support for Leonid Kravchuk and Viacheslav Chornovil, who were voter favourites. Chornovil won the highest percentage of votes in the Ivano-Frankivsk, Lviv and Ternopil regions. In contrast, these were the regions where Kravchuk had the least support. Chornovil, in turn, saw his worst results in the Crimea, Donetsk and Lugansk regions (Khobta 2000: 98) (see Figure 1).

Regional differences in support for political leaders were also clear in subsequent election campaigns (both presidential and parliamentary), with a split between the western part of Ukraine and the country's east and the south.

At the heart of this regional polarisation was, however, an ideological clash between communists and anti-communists. This was confirmed, in particular, during the 1991 presidential election campaign where Kravchuk appeared to 
personify the old school officials, communists and government appointees of Soviet times. His main political rival, Chornovil was depicted in contrast as a Soviet dissident and fighter against the Communist regime. In the next presidential election campaign in 1994, Leonid Kuchma claimed Kravchuk's former role, and Kravchuk therefore positioned himself as an ideological opponent of communism and fighter for the democracy. As a result, he received overwhelming support in the Ternopil (94.8\% of votes), Ivano-Frankivsk (94.46\%), and Lviv regions (93.77\%) where voters in previous presidential elections had voted against him and given his former opponent (Chornovil) an absolute advantage (Korzh 2007: 94) (See Figure 2).

During this time, Ukraine was experiencing a kind of renaissance of communist ideology so that democratic positions won out only in the west of the country where memories of the crimes of the Soviet totalitarian regime were most fresh. In 1991 and 1994, the "anti-communists" lost in the central and south-eastern regions and were therefore defeated nationally. Ukraine's regional polarisation reflected an ideological conflict between two political sides that might be loosely called "communist" and "democrat." This pattern was observed in subsequent presidential and parliamentary cycles. All this changed, however, in 2004.

\section{Election campaigns and political manipulation in the "post- -ideological" era (2004-2012)}

It is widely believed that the 2004 presidential election campaign marked the end of ideology-based competition in Ukrainian politics and the dawn of the age of axiotechniques. This campaign was based on an artificial line-up of - and aggressive emphasis on - different values and priorities across the country.

The issues on which these electoral axiotechniques were based included

- the Russian language's status in Ukraine

- the politics of heritage including questions about the Kievan Rus', the Treaty of Pereyaslav (1654), the role and place of the October Revolution in Ukraine's history, the Great Famine of 1932 - 1933, the Great Patriotic War (World War II), repression, collaboration, Organizacija Ukrajinskych Nacionalistiv - Ukrajinska Povstanska Armija (En. "Organization of Ukrainian Nationalists - Ukrainian Insurgent Army"), the "glorification" of controversial historical figures (Mazepa, Shukhevych and Bandera on the one hand and Peter I, Catherine II, Lenin, Stalin and Brezhnev on the other) and the Soviet Union's dissolution

- Ukraine's geopolitical situation and the country's future in international associations and organisations (including inflammatory talk about the need to choose between "eastern" and "western" civilisations and pressure to join international economic, political and political-military bodies 
with different remits such as the EEA, EU, NATO and the Customs Union with Russia) and

- religion and confession (as seen particularly in clashes between Orthodox denominations and issues around the Ukrainian Greek Catholic Church (UGCC) etc.).

Starting in 2004, speculation around these topics gave rise to a specific system of social symbols, myths and exaggerated regional identities on which campaign techniques were based. Moreover, from this point onwards, representatives of the same political entities began to highlight entirely different (and sometimes diametrically opposed) issues in different regions in order to win election campaigns. These issues reflected different social values or more specifically the social values of particular regions. These campaign axiotechniques were distinguished by their aggression designed to elicit negative emotional responses such as hatred, anxiety and restlessness.

The pioneers of these axiotechniques in Ukraine were the Russian political consultants Granovsky, Kulikov and Syerhyeytsev. During the 2004 presidential election, these individuals worked from the informal campaign headquarters of Viktor Yanukovych, led by Serhiy Klyueyev, are presentative of the "Donetsk clan"(Leshenko 2014).

These strategists manufactured the first electoral conflict in the history of an independent Ukraine that was based on an opposition between "East" and "West" within the country. Yanukovych's main competitor, Viktor Yushchenko was identified with the threat of "Ukrainian nationalism" and linked to Ukraine's transformation into a "puppet of the West"and especially of the United States. At the same time, the term "nashysty" (Nazis) was introduced to denounce Yushchenko's party Nasha Ukraina (Our Ukraine). Southern and eastern Ukraine were singled out as the bastions of Yanukovych's support. Thanks to an aggressive media campaign, the public in these regions became obsessed with the prospect of a violent "Ukrainisation" in the event that the nashysty and their leader came to power. The main TV stations screened a video clip widely thought to be the work of the political strategist Granovsky. A kind of caricature, it depicted the map of Ukraineasan animal carcass that had been divided into various cuts of meat: the west was "first grade," the centre "second grade" and the east and south "third grade" (see Figure 3).

This charge of segmentation of the country was addressed specifically to Yushchenko and his followers. Both videos and print publications circulated the myths that Yushchenko's father had served in the Third Reich army during World War II and that Yushchenko himself supported fascist ideology and aspired "like Hitler to conquer Ukraine and desecrate the memories of our grandfathers who fought fascism to restore peace to their land." Other supposedly incriminating materials authored by Russian political consultants portrayed Yushchenko as a "servant of the Catholics, heretics and schismatics [representatives of the 
Ukrainian Orthodox Church - Kyiv Patriarchate (UOC-KP), Ukrainian Autocephalous Orthodox Church (UAOC) and UGCC]" (Smoliy-Levenets 2007: 773).

Yanukovych, on the other hand, was cast as a strong but fair politician and an experienced economic decision-maker. Most critically, he was said to be a "true believer," a supporter and protector of the orthodoxy and a defender of the Russian language and the Russian-speaking population in the country's south and east. The blatant manipulation of issues that this entailed is clear from the following facts:

1. Yanukovych's official programme for the Central Electoral Committee concerning his presidential candidacy made no mention of the protection of the Russian language or the need to safeguard Russian as a second state language. Instead, this "problem" was introduced by political strategists during the election campaign in a bid to heighten tensions between groups in the electorate.

2. A significant part of Yanukovych's campaign strategy focused on the mass coverage of his "warm" relations with the leadership of the Russian Orthodox Church and its Ukrainian chapters including the Ukrainian Orthodox Church of the Moscow Patriarchate (UOC-MP). The campaign, thus, highlighted the clergy's active support (including political and financial aid) for Yanukovych in his roles as governor of Donetsk region and prime minister of Ukraine. This public rhetoric tilted the delicate balance of power among Ukrainian churches in favour of UOC-MPA. Though the latter was the largest church in Ukraine in 2004, it represented the religious preferences of less than $40 \%$ of believers (Religious Informational Service of Ukraine 2017).

By championing UOC-MP in their efforts to mobilise voters and manipulate their religious feelings and beliefs, Yanukovych, his political advisers and their entourage only fragmented the state's religious sphere. Given that Ukraine's major churches do not have an equal impact and specific churches dominate in specific regions (UOC-MP, for example, holds sway in the southern and eastern parts of the country), this move automatically divided the symbolic (and, for the purpose of campaign techniques, electoral) space by creating destructive regional identities and opposing them to one another.

For the sake of objectivity, we should note that Yushchenko's team also tried to use powerful campaign axiotechniques. To this end, they appealed to the Ukrainian electorate by disrupting the debate over the United Ukrainian Orthodox Church's origins and manipulating constituents' desire to join the EU. In 2004, the EU goal was shared by $70.7 \%$ of population in the west, Yushchenko's main support base, according to Razumkov Research Centre (2007). Other sociological studies suggest that support for the idea was significantly weaker in other regions at this time. The appeal in western Ukraine can be explained by the fact that the region is closer to EU borders. We should also note the popularity of the European directive on labour-based migration for EU citizens. The European integration promised by Yushchenko would have greatly simplified work options. 
The manipulative election strategy pursued by Yushchenko's headquarters was focused on his opponent's past and had dangerous consequences for Ukrainian public discourse. Among its effects was the introduction of terms like "Donetsk mafia," "Donetsk criminals" and "Donbass bandits," which automatically associated the residents of eastern Ukraine in general and Donbass in particular with criminality. Use of these axiotechnique-driven slogans in the media reinforced disparaging regional identities and the political opposition between the regions. At the same time, it weakened the already fragile sense of Ukrainian civic identity.

Nevertheless, the axiotechniques deployed from Yanukovych's headquarters were considerably more devastating, a fact that can be explained solely by way of the campaign's technical capabilities. Given the pressure of his overall administrative role, Yanukovych's appearances in the national and regional media exceeded Yushchenko's by 210 times (at the time, Yanukovych was prime minister of Ukraine and was openly being discussed as Kuchma's successor; he commanded strong governmental support on the one hand and had the help of the richest and most powerful financial and industrial groups in the country - the so-called Donetsk clan - on the other hand) (Smoliy - Levenets' 2007: 775). Of particular note was the massive onslaught of information dispensed by the Party of Regions in the south-east (subsequent electoral cycles saw similar information campaigns by allied groups, especially Ukraine Communist Party).

The psychological impact of the axiotechniques in the regions can be seen from the results of sociological surveys. We may look, for example, at one of the surveys that was conducted soon after the 2004 presidential election (when, as we have noted, the active use of manipulative axiotechniques began) and followed up by a similar survey in 2012. In 2005, this survey asked: "Are there any political, linguistic, cultural or economic differences between the regions of Ukraine which are so profound that they might lead a region to secede and create its own state or join other states?" In western Ukraine, only $10.9 \%$ of respondents answered this question positively while $71.3 \%$ replied negatively; in central Ukraine, $14.3 \%$ of responses were positive and $72.2 \%$ negative; in the south, the results were $26.1 \%$ positive and $56.4 \%$ negative and in the east, $24.2 \%$ positive and 59.9\% negative (Razumkov Research Centre 2007).

In 2012, in contrast, far more Ukrainians believed that the division of their society was a real problem. Those in the south-east region (the electoral base of the Party of Regions and Ukraine Communist Party) believed it was the most important issue of the day (59.5\% of respondents). In the western and central regions, this opinion was shared by $34.1 \%$ and $39 \%$ of respondents, respectively, that is, three times the percentage in 2004. These figures attest to the serious harm caused by the use of axiotechniques in these regions (Razumkov Research Centre 2012). 
One of the main drivers of axiotechniques, I would suggest, was the failure of political actors to communicate with voters in the manner generally required in a democracy. According to this two-way communication system between politicians and voters, a political party first wins an election and then gains a platform from which to help make decisions that are important to the community. In Ukraine, political advertising worked at first to fill some of the communication vacuum between the people and those in power. It promoted public awareness about particular politicians and between 1998 and 2004,helped parties gain support and take office through strong information campaigns directed at voters.

Nevertheless, the effectiveness of this approach declined gradually because of the irregularity of this advertising (it was concentrated in the lead-up to elections). This strategy was also unilateral: specially crafted and often biased messages were dispatched from the "centre" (the president, the government, the party in power) to the citizens who were, in fact, deprived of the chance to influence the decision-making process.

Campaign axiotechniques emerged as an artificial way to distract voters from the serious problems surrounding political communication in the Ukrainian public domain without making any effort to solve them. This was also an attempt to mobilise voters and gain their support. With this goal, the electoral space of modern Ukraine was carved up among the major political players during presidential and parliamentary elections between 2004 and 2012 in a division of Ukrainian society based on simulated values.

Over the course of parliamentary elections in 2006, 2007 and 2012, the uncontrolled use of manipulative campaign axiotechniques destroyed Ukrainians' sense of national identity and established divisive regional identities. It is worth taking a more detailed look at these elections. During the 2006 campaign, electoral support for the leading political parties followed the geographical patterns seen in the 2004 presidential election. Led by Viktor Yanukovych, the Party of Regions was the electoral favourite in eight regions in the east and the south (the Dnipropetrovsk, Donetsk, Zaporizhia, Luhansk, Mykolaiv, Odessa, Kharkiv and Kherson regions) as well as Crimea and Sevastopol- the same places where the party had triumphed in 2004 (Central Election Committee of Ukraine 2006) (see Figure 4).

In 2006, former Yushchenko's supporters have been devided between two political parties: Nasha Ukraina and Yulia Tymoshenko Bloc, which together won in the same areas that Yushchenko had claimed in 2004 (i.e. the central and western regions comprisingVinnytsia, Volyn, Zhytomyr, Ivano-Frankivsk, Kiev, Kirovograd, Lviv, Poltava, Rivne, Sumy Ternopil, Khmelnytsky, Cherkasy and Chernihiv; see Figure 4).

In percentage terms, the leads of the top parties in most of these regions were not as striking as they had been in the 2004 presidential elections. Nevertheless, there was a very significant difference between these margins in Halychyna 
(Ivano-Frankivsk, Lviv and Ternopil regions) and the ones in Donbass (Donetsk and Lugansk regions) (Central Election Committee of Ukraine 2006).

As for campaigning tools, the political forces that made the most aggressive use of manipulative axiotechniques gained the most voter support. In 2006, the Party of Regions and Yulia Tymoshenko Bloc were, thus, voter favourites. The Party of Regions sought to incite fear in the electorate about the likelihood of future economic collapse if another party was successful. At the same time, the Party's campaign addressed the particular concerns of certain religious, ethnic, social and other groups. On this basis, it attacked NATO and backed Russian as a second state language and membership of the Eurasian Economic Community without giving much explanation of the advantages of these positions; instead, it relied on stereotypes and prejudices within the electorate (Central Election Committee of Ukraine 2007).

The political strategists of YuliaTymoshenko Bloc also used aggressive techniques. In public speeches, Tymoshenko tapped into the sense of hurt among "Orange" voters, who considered they had been cheated by some members of the Party of Regions (Bachevskij 2006). In contrast, other political parties (e.g. Ukraine Socialist Party, Ukraine Communist Party, Nasha Ukraina and Lytvyn Bloc) that did not stage a clash of values but only reiterated their achievements, had unexpectedly low levels of voter support.

The 2007 snap parliamentary election saw no change in the regional distribution of voters' preferences for leading parties from the pattern in the last two nationwide elections. By this stage, however, manipulative axiotechniques had become a mainstream political tactic.

During this campaign, political operatives in Ukraine Communist Party and Lytvyn Bloc tried to learn from the failure of their previous campaign strategies. Both parties made drastic efforts to hang onto voters. This is especially clear from the manipulative axiotechniques used by the Communist Party whose focus on regional identities was obvious. One of the party's advertising spots, thus, played overtly on divisions in society, posing the question: "Who do you descend from - the Vatutins and Kovpaks, or the Banderas and Shukhevyches?" (Kutsenko 2012). Arguably, it was because of these techniques that Ukraine Communist Party managed to improve its election result, winning almost twice as many votes as it had in previous campaigns (its level of support increased from 3.66\% to 5.39\%) (Central Election Committee of Ukraine 2007).

The 2009 - 2010 presidential campaign was unique in several ways. To begin with, there was almost no difference in the content of the political programmes of its participants (there were 18 presidential candidates). Secondly, because of the mass poverty in Ukraine in the wake of the 2008 - 2009 global economic crises, economic wellbeing was the foremost concern among Ukrainians. Against this background, topics such as geopolitical and linguistic preferences, heritage, religion and security policy that had been critical to the development 
of axiotechniques in election campaigns since 2004, were now thrust aside. Meanwhile, all candidates appealed to left-wing populism as the most effective means of capturing the electorate's attention.

There were five leading candidates in the 2010 presidential elections: Yushchenko.Yaceniuk, Tigipko, Tumoshenko and Yanukovich, and together they received $85.84 \%$ of all votes (Central Election Committee, 2010; Official results of the first Presidential elections' round 2010). These politicians can be provisionally divided into two main groups: those in the "Orange" camp (Yushchenko, Yaceniuk and Tumoshenko) and those on the "Blue and White" side (Yanukovich and Tigipko, who had headed Yanukovich'spresidential campaign during the controversial 2004 elections). Both camps relied on the manipulation of values in the electorate as one of their chief tools in the political struggle.

During the 2009-2010 presidential campaign, the two camps found another common tactic in left-wing populism. All their candidates vowed that on becoming president, they would modernise Ukrainian factories, schools, universities and hospitals and so make Ukraine one of the most economically powerful countries in the world (or, as Yanukovich promised, a member of the G20 Electoral platform of Viktor Yanukovich 2010).

As we have seen, the manipulation of voters' geopolitical and linguistic preferences did not have the same major impact on the 2010 presidential elections that it had on previous campaigns (and would have again on the 2012 campaign). Nevertheless, aside from candidates' personal traits, it was the single factor that distinguished them in the campaign.

Two of the three Orange representatives (Yaceniuk and Tumoshenko) set out to win the support of voters from all Ukrainian regions. To this end, they distanced themselves from the images of themselves they had promoted in previous campaigns. Yushchenko on the other handheld fast to his past values, insisting that Ukrainian should be preserved as the only state language and that the EU and NATO were Ukraine's ideal geopolitical partners. In earlier campaigns, the number of voters who had been swayed by these political appeals had been relatively high, and Yuschenko had, thus, won the votes of 10.5 million people (almost $45 \%$ of all participating voters) in the 2007 Ukrainian parliamentary snap elections (Central Election Committee, 2007). In contrast, he lost public support during his presidency and only managed to attract $5.45 \%$ of all votes in 2010 (Official results of the first Presidential elections' round 2010) despite the political niche he had established.

Yaceniuk, a young politician who had become very popular before the campaign (receiving up to 12\% of votes in 2008-2009 according to research (Reytyng Yaceniuka vyros bolee chem. V dva raza, 2009) and later revised his political image and values, did not do much better than Yuschenko. Yaceniuk finished with $6.69 \%$ of the votes in 2010 (Central Election Committee, 2010). 
One reason for this poor result was his departure from the main positions of the Orange camp. He described his reformulated positions as follows:

- "Discriminating against the Russian language is unacceptable... Avoiding this discrimination will support the Ukrainian language's development step by step" (Electoral platform of Arseniy Yaceniuk 2010).

- "Ukraine's main problem is its perpetual desire to be integrated somewhere else... Instead of doing this, it should become the leader of east European civilisation and unite Azerbaijan, Belarus, Armenia, Georgia, Kazakhstan, Moldova and Russia."Such a project, Yaceniuk claimed, would resolve the problem of Europe's division along East-West lines and offer the unity of a "'Greater Europe' - an economic, political and security integration under taking for all countries of Eurasia” (Electoral platform of Arseniy Yaceniuk 2010).

- The "split" in Ukraine, he said, could only be healed after "resolving the problem of Europe own division (into West and East)" (Electoral platform of Arseniy Yaceniuk 2010).

Tumoshenko was the most successful of the Orange candidates, receiving $25.05 \%$ of votes (Official results of the first Presidential elections' round 2010). Nevertheless, she struggled against Yanukovich in the second round of the presidential elections, which Yanukovich ultimately won with $45.47 \%$ of all votes (just 3.48\% more than Tumoshenko) (Central Election Committee, 2010).

Among the reasons for Tumoshenko's loss were (1) conflict in the Orange camp and the failure to settle on just one candidate; (2) Tumoshenko's departure from the political values of the Orange movementas she tried to gain support in east and south Ukraine and (3) Tigipko's nomination as an alternative Blue and White candidate to Yanukovich. On the latter point, experts noted that Tigipko had captured between $6.5 \%$ and $8 \%$ of Tumoshenko's potential votes (Kak Yanukovich i Tymoshenko podelili izberateley Tigipko, Yaceniuka, Yuschenka, Symonenko 2010). Significantly, Tigipko had a similar election programme to Yanukovich. He argued that local government should regulate language usage in each region while also promising to "restore Russian to the role of Ukraine's language for international communication." (Electoral platform of Serhiy Tigipko 2010) For Tigipko, Ukraine was "Europe, but not the EU" (Electoral platform of Serhiy Tigipko 2010) and Ukrainian foreign policy required a multi-pronged approach (partnerships with both Russia and the EU) with an emphasis on the Russian connection.

Tigipko did not directly rule out the possibility of Ukraine becoming part of NATO. But his promise to "start creating a new military doctrine immediately on taking office" (Electoral platform of Serhiy Tigipko 2010) was tantamount to a rejection of NATO. The "old" doctrine developed by Yushchenko had envisaged NATO membership as part of Ukraine's future. 
For his part, Yanukovich did not change his agenda after his unsuccessful presidential campaign in 2004. In 2010, he again called for Russian to be made the second official state language along with a deeper partnership with Russia and Ukrainian neutrality concerning military blocs (Electoral platform of Viktor Yanukovich 2010)

At the same time, it should be noted that Yanukovich's campaign managers did not emphasise these plans for closer cooperation with Russia throughout Ukraine; instead, they were the focus of the campaign in the country's south-eastern region. Banners with the message "Crimean prosperity through friendship with Russia!" (Ostriakova 2016) were, thus, hung in the streets of Crimea.

Unlike the 2010 presidential campaign, the 2012 parliamentary elections were mired in manipulative tactics, including campaign axiotechniques. Politicians began this manipulation long before the official campaign began. In June 2012, members of Ukrainian parliament from the Party of Regions and the Communist Party, thus, pushed through anew "language law" known as the Kivalov-Kolisnichenko law after the pro-Russia politicians who were its authors (Lelich 2012). This law effectively reduced Ukrainian's status and declared Russian to be a second unofficial state language.

This step by Yanukovich's parliamentary faction met with sharp criticism from Ukrainians, especially Ukrainian intellectuals. Nevertheless, the situation proved profitable for pro-Russian regionalists and their leader, President Yanukovich, who wished to show the electorate that he kept his promises in the lead-up to the 2012 autumn parliamentary elections. At the same time, this was the perfect chance for the so-called democratic camp (the All-Ukrainian Union (Batkivshchyna), Svoboda and Ukrainian Democratic Alliance Reform parties) and its leaders (Yaceniuk, Turchinov, Tyahnybok and Klitschko) to mobilise "patriotic" voters and demonstrate that only "democrats" knew how to defend Ukraine. While the democratic opposition had the legal options of blocking the language law's adoption in parliament or protesting the unconstitutionality of that adoption before the courts (and indeed less than a half the parliamentary deputies had supported the law), it decided against these routes; instead, it provoked massive street fights and brawls between Ukrainian language supporters and police. These events, widely known as the "Language Maidan," destabilised the country politically. In 2012, there were 380 "language" protests and the issue, thus, drove $80 \%$ of all protests in the country. Of these protests, $92 \%$ consisted of speeches in defence of the Ukrainian language or against laws proposed by the authorities or the already adopted language law (Ishenko 2013: 65).

1 The term "Maidan" derives from MaidanNezalezhnosti (Independence Square), the central square in Kiev that has been the site of political protests since the start of the independence movement. The word "Maidan" has come to be associated with ideas of peaceful resistance and determined action; see https://www.yahoo.com/news/ukraines-euromaidan-whats-name-090717845.html 
The language law effectively polarised the electoral space in Ukraine, locating the Party of Regions and the Communist Party as defenders of Russian on one side, and Svoboda, the All-Ukrainian Union (Batkivshchyna) and Vitali Klitschko's Ukrainian Democratic Alliance for Reform (UDAR) as Ukrainian defenders on the other.

The language law and the Language Maidan received widespread media coverage and changed the agenda of the parliamentary elections in ways that benefited representatives of both political camps. According to the research of Razumkov Centre, in October 2012, about 22\% of respondents had a more positive opinion of the Party of Regions as a result of the language law's adoption (Foundation Democratic Initiatives 2013). This translated to $42.5 \%$ of voters in Ukraine's south and $37.5 \%$ in the east. Meanwhile, the All-Ukrainian Union (Batkivshchyna) and Svoboda were backed by $28 \%$ and $39 \%$ of respondents, respectively, having gained the votes of those determined to elect public opponents of the language law (Foundation Democratic Initiatives 2013).

The results of the 2012 election revealed the unprecedented power of campaign axiotechniques. Those who manipulated voters' values most cynically were rewarded with the highest electoral dividends. The proof of this thesis is best seen in examples from political parties on the FarRight (Svoboda) and the FarLeft (Ukraine Communist Party). The Communist Party received two-and-a-halftimes more votes in $2012(13.18 \%)$ than it had in the previous election in 2007 (5.39\%). Similarly, Svoboda attracted 15 times more voters in 2012 $(10.44 \%)$ than it did in the last election $(0.76 \%)$ (Central Election Committee of Ukraine 2012; 2007).

The Communists' axiotechniques emphasised feelings of nostalgia for the "good old USSR days." At the same time, they drew on strong criticisms of Western democracies (including both the EU andthe US); opposition to international and intergovernmental organisations and structures (the Communists, thus, called for an "end to Ukraine's cooperation with the International Monetary Fund and the revising of all unfair international treaties beginning with the ones established under the World Trade Organization") (CPU 2012); open support for Russia and the welcoming of Ukraine's entry into geopolitical and geo-economic alliances with Russia ("our foreign policy priority is to join the Customs Union, the Common Economic Space and the Eurasian Economic Union, " the Communists noted (CPU 2012)); endorsement of Russian as a second state language and the rejection of Maidan-style techniques and other historical interventions ("We won't let them rewrite history!" (CPU 2012) they pledged). The party called for the glorification of the Soviet past (including Lenin, Stalin and World War II heroes) and the criminal conviction of "alternative" figures (especially the leaders of the Ukrainian Insurgent Army and those who cooperated with them) (CPU 2012). 
The party's political rhetoric was also saturated in Soviet-style populism. The Communists, thus, proclaimed that unlike "those who merely make promises, [we] will establish price controls and install order" and "only the Communists will restore the old ways" and so on (CPU 2012). This strategy of exploiting voters' values was most effective in the south-east where the Communists won $21.15 \%$ of all votes, putting them in second place behind the Party of Regions in Crimea, Sevastopol and eight districts in the region. In contrast, the Communist Party had less support in the central (10.1\%) and western $(3.83 \%)$ regions (Central Election Committee of Ukraine 2012).

For Svoboda on the other hand, the main source of campaign axiotechniques was the intransigent political struggle for Ukrainian independence and opposition to all political agents working against it. Based on the party's 2012 official election programme and the statements of its leaders, Svoboda's ideological orientation was nationalist-communist: its proponents aimed to increase the country's influence by advancing Ukrainians' own (mainly nationally defined) interests and a strong social welfare policy (VO Svoboda 2011).

The values targeted by Svoboda's campaign techniques are clear from the party's main messages to voters: Svoboda, it claimed, had created the historic "Revolution on Granite," destroyed occupiers' monuments and brought down the "raikoms" (Communist Party district committees). It was, thus, an oppositional force that was ready to resist criminal regimes. "We can't be bought; we won't sell out; it's impossible to break us, "the party insisted in its publications (VO SvobodaYouTube Channel 2012).

During the 2012 election campaign, these politicians also manipulated public memory. Among other strategies, this involved the identifying of past enemies (Lenin, Stalin, etc.) with more recent ones (Yanukovych, Azarov, Tabachnik, Putin, Medvedev, etc.); appeals to the sacred ("God-given country"); rhetorical and emotional manipulation (based on oppositions of "us"/ "them" and "enemies"/"heroes") and a focus on external enemies ("Moscow agents" "Soviet occupiers" etc.).

This approach to the political conflict led to a wave of protests in March 2010 concerning the appointment of Dmytro Tabachnykas Ukraine's Minister of Education, Youth and Sports under Mykola Azarov's government (the so-called anti-Tabachnyk campaign (V Ukrajini stvoryly koaliciyu Anty-Tabachnyk 2010). It also resulted in growing support for a Tax Maidan, a Language Maidan and a Euromaidan.

On the eve of the 2012 parliamentary election, Svoboda's leader Oleh Tyahnybok publicly stated that Ukraine's tax and pension codes were part of a campaign of "economic terror and political genocide." As a result, he said, his party was "bound to overturn these anti-Ukrainian laws and follow a 'small business, low tax, big business, high tax' approach” (VO Svoboda YouTube Channel 2012). 
Concerning other aspects of cooperation with the business sector, Svoboda maintained that its goals were "establishing European-level minimum wages and pensions," "eliminating the gap between rich and poor, stimulating the development of the middle class" and "not taxing migrant labourers who returned to Ukraine and were investing in the domestic economy."These policies reflected the party's efforts to win voter support in the lead-up to the 2012 election by appealing to popular values and priorities in the western and central regions especially. These were the same regions where small businesses were concentrated, and for many Ukrainian families, those businesses were not just highly valued but the very source of their livelihood. People from these two electoral regions also made up the largest proportion of migrant workers in the EU. They were more attached to European-level social payments because they were familiar with the amounts concerned having spent more time in the EU than their fellow citizens in south-east Ukraine.

In contrast, those causing harm to small businesses and other interest groups were denounced as members of the "party of power" and accused of being "Ukrainophobes who wanted to 'russify' Ukraine and take revenge for the Soviet empire." (VO Svoboda YouTube Channel 2012) Only Svoboda, it was claimed, could prevent this fate. This all-Ukrainian union vowed that it would overturn the language law. In addition, it would recognise the members of Ukrayins'ka Povstans'ka Armiya (UPA) who had fought for Ukrainian liberation and independence and provide them with the good benefits and compensation they had not received since independence. Among the wide-ranging changes that Svoboda promised were making 14 October (UPA day) a national holiday; implementing lustration; restoring nationality information to birth certificates and passports; lowering public utilities rates; "saving "the medical and education sectors; stopping strategic enterprises from being privatised and ensuring the re-privatising of illegally privatised entities. The party also pledged to lead a series of other- for the most party openly populist - initiatives that would help "change everything for Ukrainians" (VO Svoboda YouTube Channel 2012).

In 2012, campaign axiotechniques were most effective in single-member constituencies (the 2012 elections were based on a mixed/parallel voting electoral system whereas a proportional system had been used in 2006-2007). In each of the electoral regions reviewed in this study, different values were prioritised. In the west, for example, the main focus was on devotion to the Ukrainian state, patriotic initiatives and the strength of the opposition movement. This is clear from campaign statements by and about different politicians: "I guarantee that Taras Batenko will serve you and Ukraine faithfully and honestly" (Lukyanenko); "Only a united opposition can stop Yanukovych's bulldozer" (Kanivets); "He will never let this country be a carcass" (Gritsenko); "Defying the repressive state, he erected a monument to Stepan Bandera" (Lopushansky); "Freedom soldier" (Myhalchyshyn); "Experienced fighter” (Stetskiv) 
In contrast, the main messages in the south-east concerned nostalgia for the Soviet Union, cooperation with Russia and Russian's status as a second state language: "Sergei Shakhov has a Soviet team!" (Shakhov); "We are Ukrainians, and we will speak in our native Russian language!" (Lyutikov); "Petrov is ready! Decide! Act! Join!" (Petrov); "Our grandfathers fought for their country! Now let us be worthy of their great deeds! We'll win this together!” (Berezhna).

In the single-member districts of the central region, the successful candidates were in fact majoritarians, whose messages and slogans stressed pragmatism: "NizhynTeploMerezhi[a utilities company] says that with the help of Kurovsky MP, heat will be restored to your home on 16 August" (Kurovsky); "Concrete deeds; honest intentions" (Lukashuk);"Caring for the citizens of Kamianets-Podilskyi!" (Melnichenko).

\section{Conclusion}

Since Ukraine became independent, the history of elections in the country has fallen into two distinct periods. During the first (1991-2004), the race for electoral support took place between politicians from different ideological camps, with "communists" on one side and "anti-communists/democrats" on the other. Voter support for these camps followed clear geographic boundaries. While the "communists" were more popular in the east and south of Ukraine (and especially in the Crimean, Donetsk and Luhansk regions), the "anti-communists" held sway in the western and central regions (particularly Ivano-Frankivsk, Lviv and Ternopil).

In my view, 2004marked the dawn of a new age of campaign management. Its distinctive feature lay in the development of campaign techniques that did not draw on political ideology (which had effectively lost its abilityto mobilise Ukrainian voters) but on the manipulation of political values underlying the national/civic identities of Ukrainians.

Research into the development of these techniques occurs at the crossroads of existing studies of political manipulation and work on societal division. To date, however, no special definition has been offered that would help distinguish these techniques from other types of manipulation. It is for this reason that I have suggested the term "campaign axiotechniques."

The earliest use of these techniques in Ukraine took place during the 2004-2005 presidential elections. Their developers were the Russian political consultants Granovsky, Kulikov and Syerhyeytsev, who worked from the campaign headquarters of Yanukovych, a politician who was determined to win the race at any price.

Campaign axiotechniques manipulate real as well as mythic historical and culture differences among Ukrainians, who live in diverse regions. As such, the main danger they pose is their likelihood of polarising Ukrainian society. 
Between 2004 and 2012, the political struggle in Ukraine was in fact conducted between two camps - the Orange and Blue and White blocs - which had been formed before the 2004 presidential race. From 2004 to 2010, the Orange camp consisted of three main political parties: Nasha Ukraina (known as the Nasha Ukraina-Narodna Samooborona alliance from 2007 to 2009 and led by Yushchenko, Ukraine's president from 2005 to 2010); Lytvyna (led by Volodymyr Lytvyn, the Ukrainian parliamentary speaker from 2002 to 2006 and again from 2008 to 2012) and Yulia Tymoshenko's Bloc (led by Tymoshenko, who served as Ukraine's prime minister in 2005 and again from 2007 to 2010). Following the defeat of all Orange candidates in the 2010 presidential race, the camp transformed itself into the so-called democratic bloc. The latter included two new political parties, Svoboda (led by Oleh Tiahnybok, a member of parliament from1998 to 2006 and again from 2012 to 2014) and UDAR (led by former professional boxer Vitali Klitschko, a member of parliament from 2012 to 2014 and the mayor of Kiev since 2014). They were joined by the Batkivshchyna party whose leader during the imprisonment of Yulia Tymoshenko was Arseniy Yaceniuk, Ukraine parliament's speaker from 2007 to 2008 and the country's prime minister from 2014to 2016.

Throughout these years, the composition of the Blue and White side remained stable. From 2004 to 2012, it consisted of the Party of Regions (led by Yanukovich, Ukraine's president from 2010 to 2014) and Ukraine Communist Party (led by Symonenko, who had been a member of Ukrainian parliament since1994 and would continue to serve until 2014).

The political situation in Ukraine between 2004 and 2012 may be understood as an ongoing struggle between these political camps, who made active use of campaign axiotechniques rooted in conflicting political values/identities. For its part, the Orange (and democratic) bloc developed axiotechniques based on the following set of values:

- Ukrainian language should be the only state language

- Ukraine's main foreign policy priority should be integration into the EU and NATO

- The Soviet period was a time of Russian occupation. The Ukrainians who fought against the Soviet army and security services are heroes and

- The Ukrainian Orthodox Church (Moscow Patriarchate) is used by Russia to exert influence in Ukraine. Ukraine's government should support "national" churches and work on their integration into a single Ukrainian church.

In contrast, the Blue and White camp had a completely different value system. It held that

- Russian should be the second official state language 
- Ukraine's main foreign policy priorities should be cooperating with Russia and integrating into all economic, political and military structures created by Russia

- The Soviet period was a time of Ukrainian prosperity. For this reason, anyone who fought against the Soviet army and security services should be seen as an enemy of modern-day Ukraine and

- The Ukrainian Orthodox Church (Moscow Patriarchate) is the only true Ukrainian church and it should be supported by the state.

As it happened, the 2004 elections established well-defined geographic bases for each of these camps, and these were preserved during the 2004-2012 election campaigns. The Orange and later democrat candidates were backed by the electorates in western and central Ukraine while the Blue and White bloc had the support of the eastern and southern parts of the country.

Each of these camps promoted aggressive messages, which significantly influenced voters in the different regions and played on their sensitivities about their identities. This aggressive rhetoric and the use of campaign axiotechniques restructured Ukraine's political sphere with the result that politicians who were unable to use this type of manipulation had no chance of winning the race. Furthermore, candidates who had used campaign axiotechniques previously and were already associated with one of the two value systems had to continue using these same techniques that were polarising Ukrainian society. Otherwise, they risked the loss of voter support or even total defeat (this was the predicament facing Lytvyn in 2006 and Yaceniuk and Tymoshenko in 2010).

Campaign axiotechniques were mainstream tactics in all elections between 2004 and 2012 except for the 2010 presidential elections. The latter contest was less affected by these techniques owing to external factors (the negative outcomes of the 2008 economic crises).The 2012 parliamentary campaign, however, was plagued by the use of these techniques.

In my view, this active use of axiotechniques led to the polarisation of Ukraine's electoral sphere based on voter values and later to divided opinions about the loss of Ukrainian sovereign territory. As such, this electoral manipulation may threaten not only democracy but also Ukrainian national security. Civil society institutions and law enforcement agencies should play a key role in countering the impact of these destructive techniques.

\section{References}

Bachevskij, Dmytro (2006): Chomu vygrajut' vybory, abo agresuvni texty jak najbil'sh efektyvni komunikacijni technologii. Ukrayins'ka Pravda (11 April); available at http://www.pravda.com. ua/articles/2006/04/11/3092442/ (22 May 2017). 
Balaban, Rostyslav (2007): Teorija vyborchojy systemy. Lybid', Kyiv.

Bafumi, Joseph - Shapiro, Robert (2009): A New Partisan Voter. The Journal of Politics 1(71): 1-24.

Bekeshkina, Iryna (2012): Ukrajina 2012: politycnyj portret (28 December 2012); available at http://dif.org.ua/article/ukraina-2012-politichniy-portret (28 May 2017).

Byrne, Sean (1997): Growing up in a divided society: the influence of conflict on Belfast schoolchildren. Associated University Presses, London.

Central Election Committee of Ukraine (2006): Vybory do Verhovnojy Rady 2006. Rezul'taty golosuvannia po regionach Ukrajiny (lidery); available at http://www.cvk.gov.ua/pls/vnd2006/ w6p001 (21 May 2017).

Central Election Committee of Ukraine (2007): Pozachergovi vybory do Verhovnoji Rady 2007. Rezultaty golosuvannia po regionach Ukrajiny (lidery); available at http://www.cvk.gov.ua/ pls/vnd2007/w6p001 (21 May 2017).

Central Election Committee of Ukraine (2010): Chergovi vybory Presydenta Ukrajiny. Rezultaty golosuvannia u drugomu turi vyboriv po Ukrajini; available at: http://www.cvk.gov.ua/pls/ vp2010/WP0011.Central Election Committee of Ukraine (2012): Chergovi parlaments'ki vybory 2012. Vidomosti pro pidrachunok golosiv po zagal'noderzhavnomu bagatomandatnomu okrugu v mezhach regioniv krajiny. Komunistychna partija Ukrajiny; available at http://www. cvk.gov.ua/vnd2012/wp302pt001f01=900pf7171=11.html (22 May 2017).

Communist Party of Ukraine (CPU) (2012): Povernemo krajinu narodu! Peredvyborcha programa Komunistychnoji partiji Ukrajiny 2012 r. (1 August 2012) [official party website]; available at: https://www.kpu.ua/uk/41336/povernemo-krainu-narodu-peredviborna-programa-komunistichnoi-partii-ukraini (22 May 2017).

Coons Cristian - Weber, Michel (2014): Manipulation: Theory and Practice. Oxford University Press. Oxford.

Electoral platform of Serhiy Tigipko (2010). Presidential elections 2010. Vybir narodu Ukrajiny; available at: http://vybory.osp-ua.info/ch-1_fl-vybory_presidenta_2010_prog_14.htm (2 March 2018).

Electoral platform of Viktor Yanukovich (2010). Presidential elections 2010. Vybir narodu Ukrajiny; available at: http://vybory.osp-ua.info/ch-1_fl-vybory_presidenta_2010_prog_17. html (2 March 2018).

Electoral platform of Arseniy Yaceniuk (2010). Presidential elections 2010. Vybir narodu Ukrajiny; available at: http://vybory.osp-ua.info/ch-1_fl-vybory_presidenta_2010_prog_18.html (2 March 2018).

Emr, Melanie - Writer, Staff (2013): Electoral systems in an ethnically divided society; available at: https://prospectjournal.org/2013/02/20/electoral-systems-in-an-ethnically-divided-society/ (1 December 2017).

Gubskiy, Eduard - Korableva, Galina (2003): Filosofskiy enciklopedicheskiy slovar. INFRA, Moskva. Goodin, Richard (1980): Manipulatory Politics. Yale University Press, New Haven, Conn.

Goren, Paul (2005): Party Identification and Core Political Values. American Journal of Political Science 4(49): 882-897. 
Guelke, Adrian (2012): Politics in Deeply Divided Societies. Polity Press, Cambridge.

Hernandez, Pablo - Minor, Dylan (2015): Political Identity and Trust. Available at http://www. hbs.edu/faculty/Publication\%20Files/16-012_5775a007-2276-45da-bde4-4b5d495b5712.pdf (30 November 2017).

Institute of Sociology, National Academy of Sciences of Ukraine (2015): Do Dnia Nezalezhnosti: sho ukrayintsi dumayut' pro Ukrayinu. (21 August 2015); available at http://dif.org.ua/article/ do-dnya-nezalezhnosti-shcho-ukraintsi-dumayut-pro-ukrainu (15 May 2017).

Ishenko, Viktor (2013): Protesty i represiji v Ukrajini: rezul'taty monitoryngu 2012. Centr doslidzhennia suspil'stva. Kyiv.

Jacobs, Lawrence - Shapiro, Robert (2000): Politiciansdon'tpander.Political manipulation and the loss of democratic responsiveness. University Of Chicago Press, Chicago.

Kak Yanukovich i Tymoshenko podelili izberateley Tigipko, Yaceniuka, Yuschenka, Symonenko (2010): Politika Ukrainy. Censor.net (10 February 2010); available at: https://censor.net.ua/ news/112590/kak_yanukovich_i_timoshenko_podelili_izbirateleyi_tigipko_yatsenyuka_ yuschenko_simonenko__issledov (2 December 2017).

Kasianov, Grygoriy (1999):Teorii naciitanacionalizmu.Lubid.Kyiv.

Khobta, Yuriy (2000):Vybir Ukrayiny-99. Sho dali? Lubid.Kyiv.

Kolesnikov, Oleksiy (2008): Tendenciji evoluciji vyborchych technologij v Ukrajini. Suchasna ukrajinska polityka: polityky I politology pro neji 5 (Specvypusk): 41-57.

Korzh, Ihor (2007): Vybory v nezalezhniy Ukrayini. Visnyk Centralnoyi vyborchoyi komisii 1 (24): 25-34.

Kryvytska, Olena (2015): Demarkacijni linii v etnopoliticnomu prostori Ukrajiny. IPIEND, Kyiv.

Kutsenko, Yevhen (2012): Efektyvnist' zastosuvannia vyborchych technologij na parlamentskych vyborach 2007 v Ukrajini. Naukovi zapysky IPiEND 57: 142-157.

Lazarsfeld, Paul - Berelson, Bernard (1944): The people's choice: How the voter makes up his mind in a presidential campaign. Duell, Sloan and Pearce, New York.

Lelich, Milan (2012): Rada uchvalyla "zakon pro movy". Ukrajinsky tyzhden; available at: http:// tyzhden.ua/News/54404.

Leshenko, Serhiy (2014): London'ska neruhomist' ideologa ukrayins'koho rozkolu. Ukrayins'ka Pravda. (13 May 2014); available athttp://blogs.pravda.com.ua/authors/leschenko/53722f577a5cc/ view_print/ (18 May 2017).

McDermott, Rose (2010): Emotional Manipulation of Political Identity. Politics 15(1): 103-132.

Macijevskij, Yuriy (2013): Sylaradykaliv, chyslabkist' centrystiv: sho zumovylo elektoral'nuy uspich VO “Svoboda” ta KPU?(27 April 2013); available at http://www.slideshare.net/selectsage/ ss-20922218 (22 May 2017).

Mostova, Yulia (2014): Pisnia pro Bat'kivshunu. Slova narodni. Dzerkalo tyzhnia (26 December 2014); available at http://gazeta.dt.ua/internal/pisnya-pro-batkivschinu-slova-narodni-_.html (18 May 2017).

Mychalchenko, Mykola (2011): Politychni ryzyky v sychasniy Ukrajini. IPIEND, Kyiv. 
Nagorna, Larysa (2008): Regional'na identychnist: ukrayinskiy context. IPiEND imenil.F. Kurasa NAN Ukrayiny. Kyiv.

Official results of the first Presidential elections' round (2010): Chergovi vybory Presydenta Ukrajiny. Ukrajinska Pravda; available at: https://www.pravda.com.ua/articles/2010/01/18/4630133/.

O'Flynn, Ian (2010): Democratic theory and practice in deeply divided societies. Journal of Representative Democracy 3(46): 281-293.

Ostriakova, Elena (2016): Yanukovich: "Maidan" podtolknul Krym k otdeleniyu. Politnavigator (25 November 2016); available at: http://www.politnavigator.net/yanukovich-majjdan-podtolknul-krym-k-otdeleniyu.html (5 December 2017).

Pacharev, Dmytro - Rudych, Felix (2011): Politycni instytuty i procesy v suchasniy Ukrajini. IPIEND, Kyiv.

Parris, John - Le Chemiant, Wayne (2011): Manipulating Democracy: Democratic Theory, Political Psychology, and Mass Media. Routledge. New York.

Parker, Christopher - Baretto, Matt (2013): Change They Can't Believe In The Tea Party and Reactionary Politics in America. Princeton University Press, Princeton.

Poltorak, Volodymyr (2015): Technologii modeliuvannia v elektoralnych kampanijach: paradoxy "Daunsa", “Olsena”, "golosuvannia". Visnyk Kharkivskogo nacionalnogo universitetu im. V. N. Karazina 34 (1148): 82-85.

Razumkov Research Centre (2007): Yake iz navedenych vyznacen' ukrayins'koyi nacii ye dl'a Vas naybil'sh priyniatnym? (dymanika 2006-2007, regionalnuy rozpodil) (10 September 2007); available at http://old.razumkov.org.ua/ukr/poll.php?poll_id=715 (17 May 2017).

Razumkov Research Centre (2016): Chyisnuyut' mizh zahidnymy ishidnymy regionami Ukrajiny glyboki politichni, movni, kulturni ta ekonomichni vidminnosti, sho v perspektuvi vony zmozhut' rozjednatysia i stvoryty svoji vlastni derzhavy abo vvijty do skladu inshih derzhav?. Nacionalna bezpeka i oborona 3-4: 84-87.

Razumkov Research Centre (2012): Ostannim chasom govoriat pro te, sho ukrajinske suspil'stvo rozdilulosia na dvi majzhe vorogujich i chzaregional'noju oznakoju. Jak vy vvazhajete, chy isnuje takyj rozkol suspil'stva? (14 January 2013); available at http://old.razumkov.org.ua/ukr/ poll.php?poll_id=871 (20 May 2017).

Razumkov Research Centre (2016): Chy potribno Ukrajini vstupaty do Evropejskoho Soyuzu? (regional'nyj rozpodil) (10 May 2016); available at http://old.razumkov.org.ua/ukr/poll. php?poll_id=1034 (20 May 2017).

Religious Informational Service of Ukraine (2017): Religijna merezha v Ukrajini za rik suttevo ne zminulas (12 June 2017); available at https://risu.org.ua/ua/index/all_news/state/authorities_religious_affairs/67280/(15 June 2017).

Reytyng Yaceniuka vyros bolee chem. V dva raza (2009): Politika Urajiny. Cenzor.net (16 February 2009); available at: https://censor.net.ua/news/84751/reyiting_yatsenyuka_vyros_bolee_chem_v_dva_raza_sotsiologi.

Riker, William Harrison (1986): The Art of Political Manipulation. Yale University Press, New Haven, Conn. 
Schaap, Andrew (2006): Agonism in divided societies. Philosophy \& Social Criticism 2(32): 25-39.

Shulman, Stephen (2005): National Identity and Public Support for Political and Economic Reform in Ukraine. Slavic Review 1: 54-78.

Smoliy, Valeriy - Levenets, Yuriy (2007): Ukrayina: politychna istoria XX-pochatku XXI st. Parlaments'ke vydavnyctvo, Kyiv.

Stepyko, Mychailo (2011): Ukrayins'ka identychnist: fenomen i zasady formuvannia'. Nacionalniy instutyt strategichnyh doslidgen. Kyiv.

Variy, Myron (2003): Polityko-psychologichni peredvyborni ta vyborchi technologii. El'ga, Nika Centr, Kyiv.

VO Svoboda (2011): Programa VO "Svoboda" (chynna) - programa zachustu ukrajintsiv [official party website] (12 November 2011); available at http://svoboda.org.ua/party/program/ (22 May 2017).

VO "Svoboda" YouTube Channel (2012): Oficijna agitacia VO "Svoboda" u 2012 roci (17 September 2012); available at http://www.youtube.com/watch?v=QmFtfi6tsqA (22 May 2017).

V Ukrajini stvoryly koaliciyu Anty-Tabachnyk (2010): Vgolos (23. 05. 2010); available at: http:// www.vgolos.com.ua/news/v_ukraini_stvoryly_koalitsiyu_antytabachnyk_52023.html?print.

Vydrin, Dmitriy (1991): Ocherki praktickeskoy politologii. Polaris, Kyiv.

Zolkina, Maria (2013):European integration of Ukraine: Experiences of yesterday for the development of tomorrow. Public Opinion 13: 15-27.

Yevhen Kutsenko was born in 1986 in Ukraine. In 2014, he graduated from the I. F. Kuras Institute of Political and Ethnic Studies at the National Academy of Sciences of Ukraine after completing a major in political science (honours). Since 2015, he has been a, Ph.D. student at the Institute of International Area Studies at Charles University in Prague. His thesis concerns the use of campaigning techniques in parliamentary elections in Ukraine, drawing on examples from the country's western, central and south-eastern regions. This article is a part of his, Ph.D. work. E-mail: kutsenkojeka@gmail.co 


\section{Figures}

Figure 1: The 1991 Ukrainian presidential elections

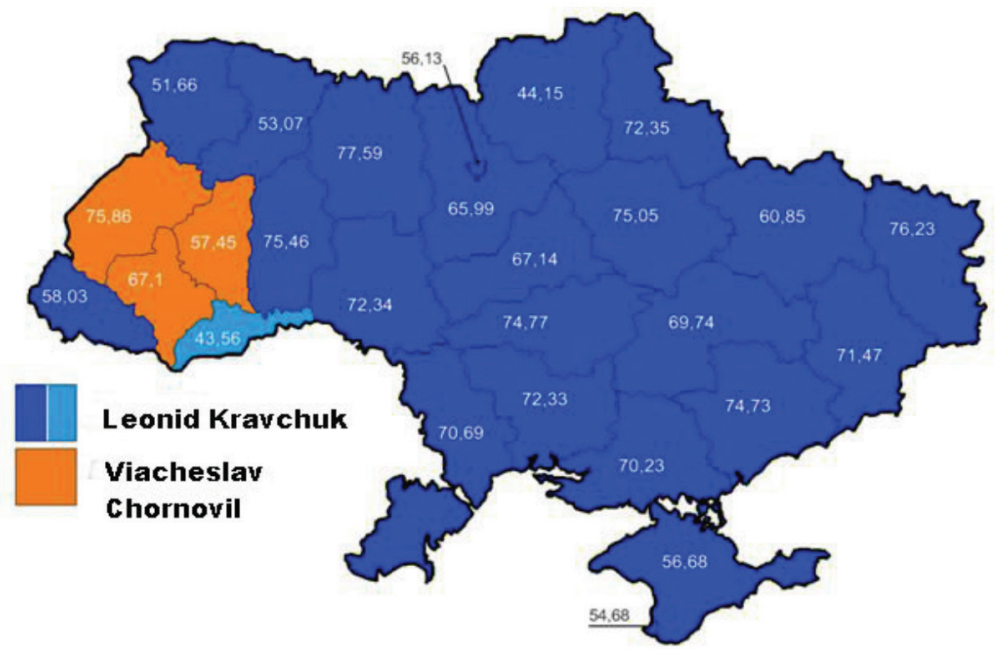

Source:http://www.electoralgeography.com/ru/countries/u/ukraine/1991-president-elections-ukraine.html

Figure 2: The 1994 Ukrainian presidential elections

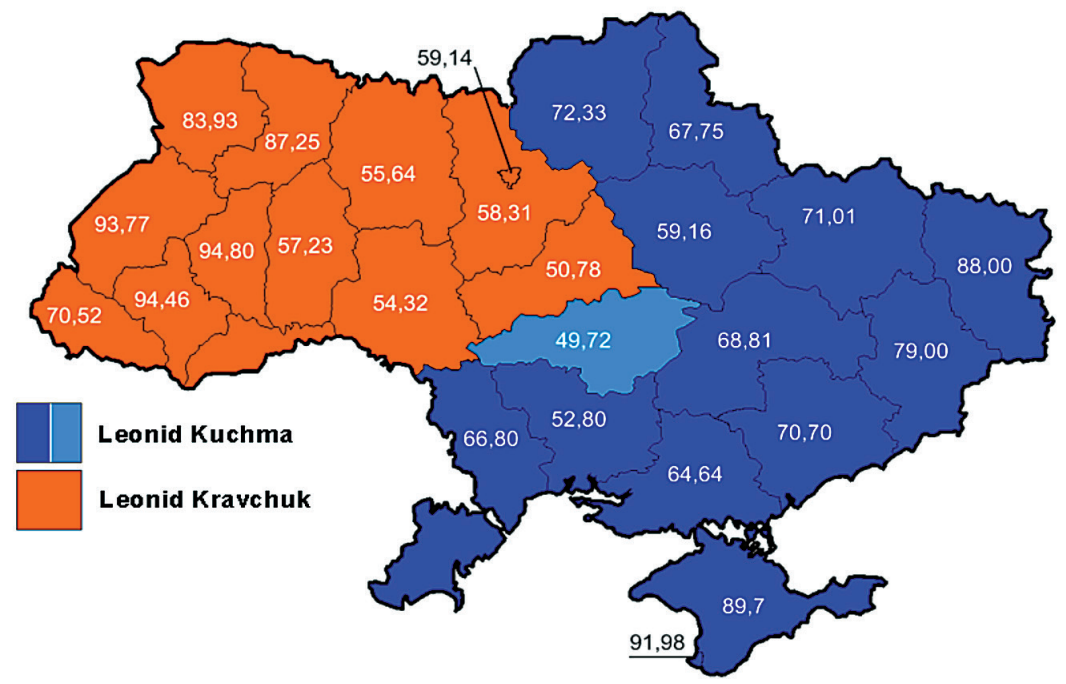

Source: https://www.electoralgeography.com/new/ru/countries/u/ukraine/ukraine-presidential-election-1994.html 
Figure 3: Manipulative axiotechniques in the 2004 Ukrainian presidential election campaign
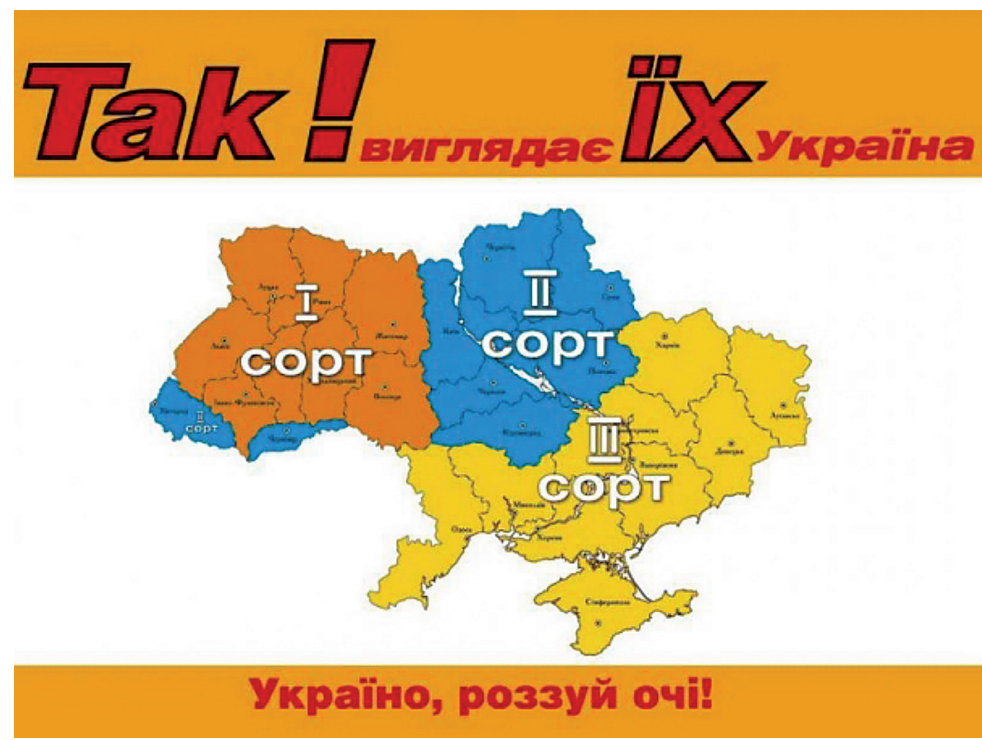

Source: http://www.pravda.com.ua/columns/2011/08/18/6505672

Figure 4: Voter support for Yushchenko and Yanukovich in the 2004-2005 Ukrainian presidential election campaign

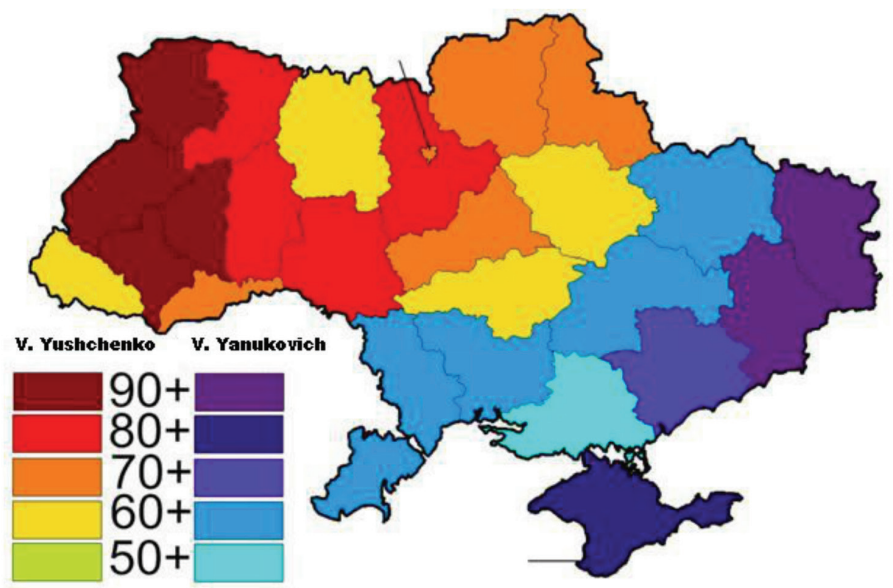

Source: http://www.cvk.gov.ua/pls/vp2004/wp0011 